Original Article

\title{
Prediction of soil seed bank of piedmont and alluvial environments of Dera Ghazi Khan, Punjab, Pakistan
}

\author{
Predição do banco de sementes do solo do piemonte e ambientes aluviais de Dera \\ Ghazi Khan, Punjab, Paquistão
}

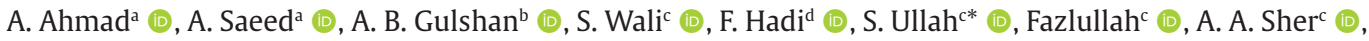 \\ M. Rizwanc (D) and M. Rafiqe (D) \\ aGomal University, Dera Ismail Khan, Khyber Pakhtunkhwa, Pakistan

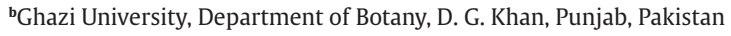 \\ 'Islamia College Peshawar, Department of Botany, Peshawar, Khyber Pakhtunkhwa, Pakistan \\ dUniversity of Peshawar, Department of Botany, Peshawar, Khyber Pakhtunkhwa, Pakistan \\ ${ }^{\mathrm{e} G o v e r n m e n t ~ D e g r e e ~ C o l l e g e, ~ D e p a r t m e n t ~ o f ~ B o t a n y, ~ D i r ~ L o w e r, ~ K h y b e r ~ P a k h t u n k h w a, ~ P a k i s t a n ~}$
}

\begin{abstract}
The current focus is on the overall pattern of seed storage present in the fragments of the soil of piedmont and alluvial landscapes of the environment. The present study predicted the seed banks of both soils of alluvial and piedmont zones in different ecological conditions and evaluate the potential of seeds in the restoration of both environments. The composition of the seed bank of soil is mainly affected by the alluvial environment and the structure of cleared area shows that more species of germinating annual grasses and growable seeds with the higher total number. Extant vegetation structures have an important role in the diversity of soil seed reservoirs, whose composition corresponded with the openness of the site. When in situ soil seed bank is recruited, it helps to restore only some components of the plant community in an alluvial environment. In our current research, it was confirmed that seed richness was higher in number at lower elevation (alluvial) than that at high elevation (piedmont). Seed richness showed a significant negative correlation with anions, cations, while significantly positive with altitude that suggests the richness pattern of the overall seed bank of the area is influenced by various environmental factors.
\end{abstract}

Keywords: alluvial, seed richness, vegetation structure, multivariate statistical package, Piedmont.

\begin{abstract}
Resumo
O foco atual está no padrão geral de armazenamento de sementes presente nos fragmentos de solo do Piemonte e nas paisagens aluviais do meio ambiente. O presente estudo previu os bancos de sementes de ambos os solos das zonas aluvial e piemontesa em diferentes condições ecológicas e avaliou o potencial das sementes na restauração de ambos os ambientes. A composição do banco de sementes do solo é afetada principalmente pelo ambiente aluvial e a estrutura da área desmatada mostra que mais espécies de gramíneas anuais em germinação e sementes cultiváveis apresentam o maior número total. As estruturas da vegetação existente têm um papel importante na diversidade dos reservatórios de sementes do solo, cuja composição correspondeu à abertura do local. Quando o banco de sementes do solo in situ é recrutado, o mesmo ajuda a restaurar apenas alguns componentes da comunidade de plantas em um ambiente aluvial. Em nossa pesquisa atual, foi confirmado que a riqueza de sementes era maior em número em altitudes mais baixas (aluviais) do que em altitudes elevadas (Piemonte). A riqueza de sementes mostrou uma correlação negativa significativa com ânions, cátions, enquanto significativamente positiva com a altitude, o que sugere que o padrão de riqueza do banco geral de sementes da área é influenciado por vários fatores ambientais.
\end{abstract}

Palavras-chave: aluvião, riqueza de sementes, estrutura da vegetação, pacote estatístico multivariado, Piemonte.

\section{Introduction}

\subsection{Seed bank}

The seed bank has an essential role in the nature and composition of ecosystems because the factors like fire, catastrophism, and fluctuation in weather, agricultural practices, and cutting of lumber disturb the re-vegetation of the area. Wetlands and forest eco-system have several specific species which form permanent soil seed banks, herbs seeds are examples of persistent species (Isselin-

*e-mail: saqibullahstd@icp.edu.pk

Received: August 8, 2021 - Accepted: September 30, 2021 
Nondedeu and Spiegelberger, 2014). Reservoir of soil seeds permit the development of species rapidly, and make the ecosystem rich due to secondary succession (Lai et al., 2020). Soil seed in litter of leaves or on organic matter surface is responsible for the growth of plants to promote their survival, so seed bank may contain seeds of single species or of many species in plant kingdom in specific region (Mensah, 2015; Veen et al., 2019). The survival of seeds depends upon many factors, the life span of seeds ranges from zero to several hundred years. Example of the oldest viable seeds of Lotus is round about 12000 years old found buried in ponds (Shiels and Drake, 2015).

\subsection{Historical perspective}

According to Charles Darwin "seed bank refers to natural storage of seed in soil" Darwin, 1859 observed the seeds and their emerging seedling using the soil samples taken from ponds soil and the soil depth of other areas. The annual plants fluctuate in their population density due to high rate of mortality of seeds in profiles of soil. The mortality of seeds in soil, and mutation are key factors for the survival of seeds. The richness of species of plants in a plant community is due to abundance of soil seed bank is known as storage effect (El-Keblawy and Bhatt, 2015).

\subsection{Significance of the study}

Many groups of plants are classified on the basis of viability of seeds buried in soil. Seeds in soil remain viable for germination only for the next available chance, while seeds of persistent floral taxa often survive more than one year. Seeds which survive more than five years form the persistent species (Long et al., 2015). A term seed diaspore is used for bryophytes and ferns; perennial plants have vegetative parts which form new plants. These diaspores, vegetative propagules, adventitious buds, stolons, rhizoids and bulbs, is also called soil bud bank (Keightley, 2020). Some ecologists worked on the climatic factors, nature, abundance of above ground and underground vegetation (Lurie and Wagensberg, 1985). The present study will contribute important data about soil seed bank and its role in diversity of plants on this planet. The main idea of this research work was to collect information about the role of geo-climatic factors and soil types in management to conserve plants as well as seeds in seed storage. In recent years the ecologists are focused on the study of conservation strategies about the sprouting time of soil seeds, because microorganism in soil destroy the seeds and hence the mortality rate of seed is increased, but the research work is still very slow.

\subsection{Piedmont and alluvial soil}

Dera Ghazi Khan the study area constitutes the land of alluvial plains and almost arable, which make this area a historic site. More over the cultivated plant varieties like fruits, vegetables and staple crops are frequently grown in this environment. This area is mainly supplied with water via tube-well from underground water, and through stream water because underground water is suitable for the growth of the plants of this area. Relatively homogenous composition of soil seeds was found among streams and along lateral gradients of the channels of water courses (Calçada et al., 2015).

\subsection{Limitations of study}

The soil storage may be developed and improvised by abandonment. The negative effects of managing the concerto of seeds in seed storage have not been quantified on large scale. As a result, the species in soil poor nutrients are disappeared, while agricultural practices improve the soil composition for the plants their soil seed bank. Hence the disappeared species can be regenerated from seeds which are stored in soil. Studies also indicates that some species grow at more than one sites particularly in grassland area depends upon the composition and viability of seeds in seed bank.

\subsection{Objectives}

Piedmont and riparian environments of study area are not previously explored to observe seed bank of soil. In our present study it was focused on overall pattern seed storage present in the fragments of soil of piedmont andalluvial landscapes of the environment. The considerable objectives of this research study are;

1. Exploration and prediction of Soil seed bank of this area.

2. The prediction of affinities of above ground vegetation from upland area (piedmont) to low land (alluvial) along the inclined gradient landscape.

3. This will suggest new trends for scholars of Botany in management and representation of soil seed bank for future studies in various fields of Botany.

\section{Methodology}

\subsection{Place of work and facilities available}

The area of study consists of Piedmont and alluvial zone of Dera Ghazi Khan (Figure 1). The piedmont area of this region is arid zone received the water in the form precipitation. The study area is located in between $30^{\circ} 3.3684^{\prime} \mathrm{N}$ latitude and $70^{\circ} 38.0862$ ' E longitude and $118 \mathrm{~m}$ (a.s.l) (Garcia et al., 2019).

The pattern of overall climate of this district is dry and receives less rainfall annually. Relatively cold in winter, while hot climate during the remaining part of the year, except in summer it is very hot weather. The range of temperature during winter is usually about 40-70 ${ }^{\circ} \mathrm{F}\left(4-15^{\circ} \mathrm{C}\right)$, while during summer season the climatic temperature of this zone is as high as $115^{\circ} \mathrm{F}$ $\left(46{ }^{\circ} \mathrm{C}\right)$. The annual mean rainfall of this area is $142 \mathrm{~mm}$ and maximum rainfall is received between June and August during monsoon. This area may receive light shower in May and September in late monsoon (Figure 2) (Munir and Iqbal, 2016).

The piedmont zone of the study area is located at high elevation. Major portion of the area rocky and comprises of Sandstone which is light grey to dark grey in colour and its grain size varies fine to coarse having limonitic coloration at some places. The alluvial zone is located 


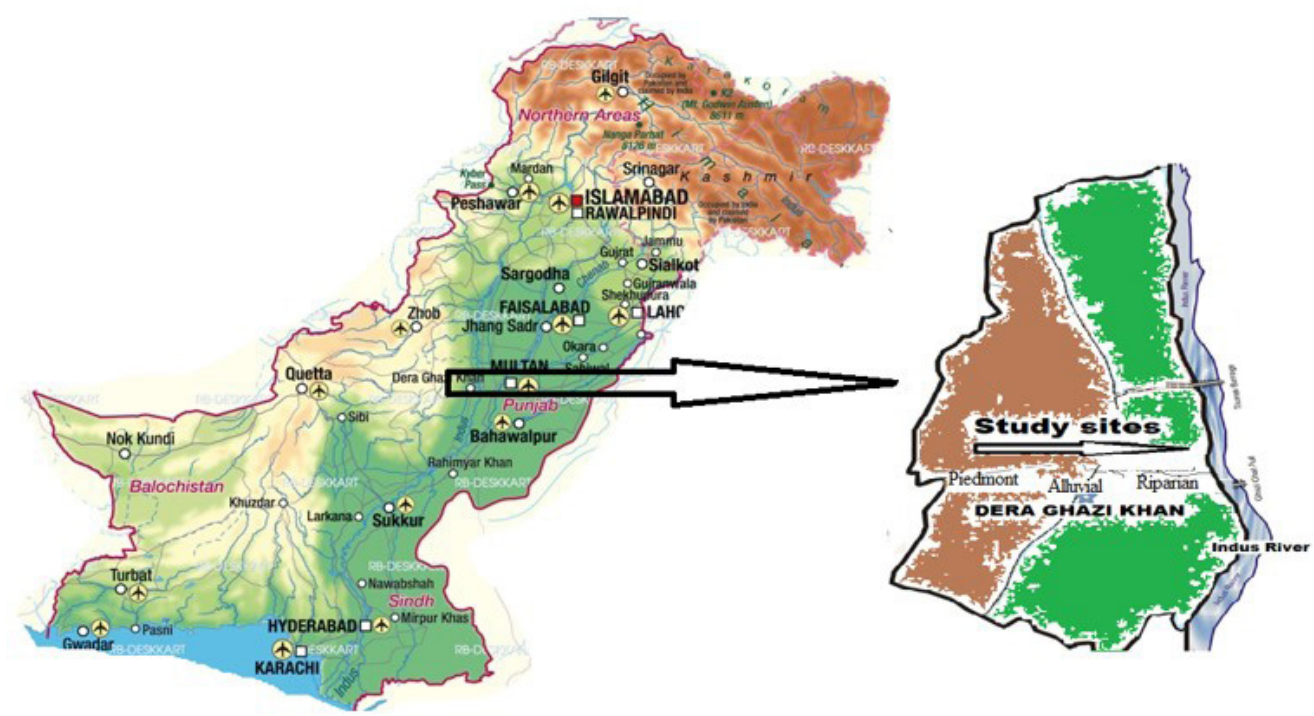

Figure 1. Showing study area (piedmont and riparian environments).

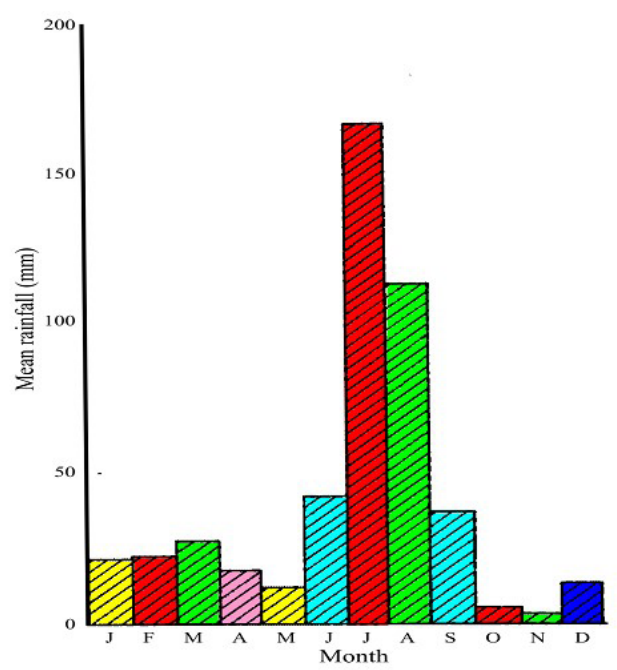

Figure 2. Mean values of monthly rainfall of the study area.

at lower elevation; however, the composition of soil indicates that it is of more than just minerals, Organic matter, and water, which is derived from a variety of parent materials. In alluvial zone water play an important role, because soils are mostly distributed under the influence of water. The minerals component with varying textures are deposited in alluvial area by the parent material of upland soils which comes as sediments carried by hill torrents, therefore the soil of riparian environment is more heterogeneous in mineral composition than their upland area (Waseem et al., 2021).

\subsection{Data collection}

Field work was carried out in spring (February-March, 2018-2019) in piedmont area from Fort Monro to Sakhi Sarwar town and the alluvial area between Indus River,
Dera Ghazi Khan, Punjab, Pakistan. The most suitable time for sampling, when most plant species are present and easily identifiable through their reproductive organs. Mid-March, was a time with highest cover for most of the species of plants. The single established transect traversed the several variety of vegetation, clearly observable to the eye located along the elevation gradient. The transect started from an arbitrary point inalluvial area to peak zone (piedmont area), gravel flat terrain located above $1500 \mathrm{~m}$ (a.s.l.) and running towards east down to alluvial sandy plains. From each stand a soil sample was taken from three different points and mixed to form a compound sample. Gravels were separated by sieving through $2 \mathrm{~mm}$ mash. Three sub-samples were drawn from this composite sample. The sieved soil samples were stored until analysed (Theocharopoulos et al., 2001).

\subsection{Soil seed bank assessment}

The soil seed bank was determined by following the method as described by (Schwartz-Lazaro and Copes, 2019). Emergence of seedlings method is simple and has the advantage for easy identification of various plant species. The use of substances like tetra-zolium chloride that promote the floatation of seed is a good technique for the separation of seeds. Many sources like animals, wind, manure, birds, insects and contaminated crops are involved in the transportation of seeds from one place to another place. These transported seeds are buried in soil and stored in the wreckage and layers of soil, hence called soil seed bank. The density and composition of soil seeds were determined by two main techniques. These techniques can also be used to find count of seeds from various soil samples.

1) Sieve method for the extraction of seeds from soil samples.

2) Seedling emergence method. 
In first method soil seeds were extracted by floatation and washing techniques directly while for seedling growth seeds will be sown in green house under controlled environmental conditions. In green house seeds will be regularly watered and after emerging of seedling, will be identified to which species they belong, their number is also counted (Sanou et al., 2018). Similarly, the plant species which are in the range of quadrate were also identified. Soil samples were collected from the depth of 6 inches below the superficial layer of soil. These collected soil samples having seed storage were put in green house to observe the dormant and germinal seeds under controlled conditions. The data of seed bank were collected from three habitats like piedmont a hilly area, sandy alluvial plains and riparian sites. Sampling area was chosen a priority based on the moist gradient.

Sampling data of seed bank was collected concomitantly from the selected sites of the study area. Seed bank samples were collected in (February-March in the year 2018-19). For seed bank five $1 \mathrm{~m}^{-2}$ quadrates were used in each sites and a total of 40 sites, samples were containing five soil cores and each soil core was $4 \mathrm{~cm}$ in diameter with $15 \mathrm{~cm}$ deep in from surface in vertical direction. The total area sampled at each site was $0.125 \mathrm{~m}^{2}$. The collected samples for soil seed bank were analysed by following the methods of (Santos et al., 2016) and (Shang et al., 2016). A fine sieve ranges size (mesh width $0.212 \mathrm{~mm}$ ) were used to separate the seeds from collected soil samples before being spread out in a very thin layer $(<3 \mathrm{~mm})$ on trays filled by soil mix with fine sand and allowed to germinate in a glasshouse for 8 weeks' duration. The trays were kept under a 12 hours' photoperiod with night and day temperatures $24 / 30{ }^{\circ} \mathrm{C}$ and sprinkling of water after 24 hours. Emergence of seeds and germination of seedling was counted on daily basis, when there was no further emergence then all seedlings had been identified, counted and removed, the samples were recollected from the trays, dried and stored at room temperature in the darkness to avoid from fatal germination of embryos until the suitable condition for the germination of remaining seeds. The germination method and seedling emergence methods to assess the soil seed bank was followed by (Mahé et al., 2021; Shang et al., 2016); (Koch et al., 2011). These are the best methods for exploring and quantifying the viable seeds form the collected soil samples The seeds which were fail to germinate were excluded from the present analysis.

\subsection{Statistical Analysis}

All the collected data except the percentage values were transformed logrithmically, so that they met the assumptions of ANOVA. Percentage values were transformed by using inverse of the sine function (arcsine) transformation (Campbell and Sofo, 2017). We used Pearson's correlation using MINITAB software package.

\section{Results and Discussion}

\subsection{Soil seedbank of two sites: Piedmont and alluvial environments}

\subsubsection{Viable seed bank}

Seed bank encountered the distribution pattern of species richness and diversity (Table 1 ). There were significant differences in soil seed bank supporting species richness and diversity (Table 1). Soil seed bank of association $A$ located at low elevation showed higher value of species richness $(S R=10.58, F=5.74, P<0.000$, Table 1$)$ and diversity $(\mathrm{H}=2.35, F=5.26, P<0.000)$ than associate $\mathrm{B}$ $(\mathrm{R}=9.40, \mathrm{H}=2.29, F=5.26, P<0.000)$ and $\mathrm{C}(\mathrm{R}=8.13, \mathrm{H}=2.21$, $F=5.88, P<0.000)$. Brillion Diversity indices and Simpson Diversity indices exhibited the similar trends of soil seed bank. A significant decrease in species richness and diversity along elevation gradient was shown in trends of soil seed bank, as correlation between seed bank and elevation inclination was highly significant (R-0.712***, Table 1 ).

\subsubsection{Normal cluster analysis}

Three plant communities were delineated by the normal cluster analysis. The lists of stands in each association are represented in the (Figure 3 ). These communities were segregated based on specifying two hierarchical levels. The most noticeable feature indicated by this analysis was the separation of Lithospheric strata belonging to Piedmont zone located at high elevation. As a result of two hierarchical levels three clusters were created.

1. Riparian zone (Association A).

2. Sandy alluvial plains (Association B).

3. Piedmont zone (Association C)

\subsubsection{Gradient analysis}

First two axes presented Site ordination plane of study area (Figure 3). The DCA-I axis of the normal data set had

Table 1. Seed bank pattern amongst the plant associations, supporting Species Richness and Diversity Indices: SR= Species Richness; $\mathrm{H}=$ Shannon Wiener Diversity index; B'= Brillion Diversity index and D = Simpson Diversity values recorded in three association.

\begin{tabular}{ccccc}
\hline Associations & SR & $\mathbf{H}^{\boldsymbol{\prime}}$ & $\mathbf{B}^{\boldsymbol{\prime}}$ & $\mathbf{D}^{\boldsymbol{\prime}}$ \\
\hline A & 10.58 & 2.35 & 1.53 & 0.90 \\
B & 9.40 & 2.29 & 1.69 & 0.87 \\
C & 8.13 & 2.21 & 1.40 & 0.85 \\
$\boldsymbol{F} \&$ P-values & $5.74^{* * *}$ & $5.26^{* * *}$ & $5.88^{* * *}$ & $4.82^{*}$ \\
\hline
\end{tabular}

${ }^{*} P<0.05 .{ }^{* *} P<0.01 .{ }^{* * *} P<0.001$. 


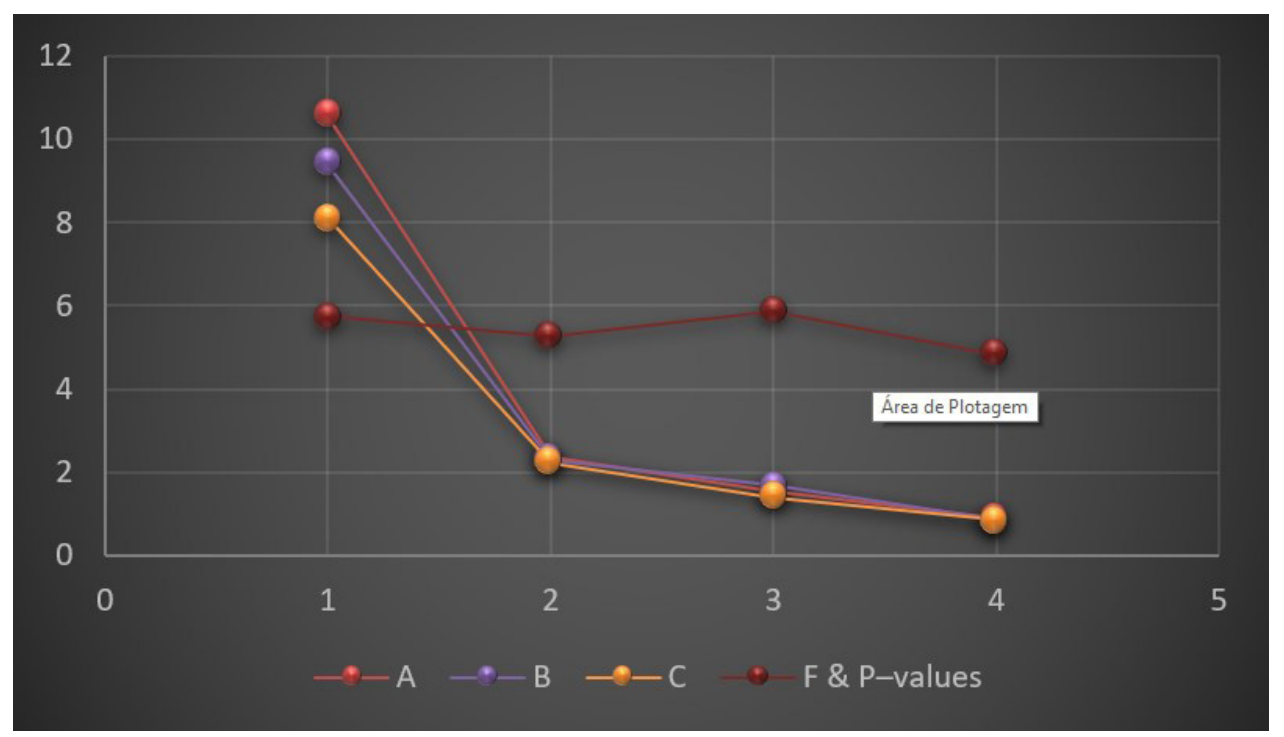

Figure 3. Seed bank pattern amongst the plant associations, supporting Species Richness and Diversity Indices: SR= Species Richness; $\mathrm{H}=$ Shannon Wiener Diversity index; B'= Brillion Diversity index and D = Simpson Diversity values recorded in three association.

Table 2. Eigen values and cumulative percentage of DCA axis 1-4.

\begin{tabular}{cccc}
\hline Axis & $\begin{array}{c}\text { Eigen } \\
\text { values }\end{array}$ & $\begin{array}{c}\text { Percentage } \\
\text { of total }\end{array}$ & $\begin{array}{c}\text { Cumulative } \\
\%\end{array}$ \\
\hline 1 & 0.812 & 39.940 & 39.940 \\
2 & 0.094 & 4.644 & 44.584 \\
3 & 0.064 & 3.135 & 47.720 \\
4 & 0.030 & 1.458 & 49.178 \\
\hline
\end{tabular}

an Eigen value of 0.812 (Table 2). The Eigen value for the axis-I was 0.094. The remaining axes showed lower Eigen values and lowest values were discarded (Table 2 ).

The ordination diagram reflects the distribution of soil buried seeds along the study region i.e., from riparian alluvial plains to Piedmont zone. The distribution of the seed bank density was significantly influenced by habitats and soil factors were not random. The species like Chenopodium album, Euphorbia prostrate, Eragrostis minor, Launaea procumbens, Nelumbo nucifera and Solanum xanthocarpum having the lowest score along DCA axis-I, belonged to the Riparian zone (Association A) with maximum soil seed bank density $\mathrm{m}^{-2}$ and presented on the left side of the ordination (Figure 4), while the species like Heliotropium eichwaldi, Scirpus maritimus, Dichanthium annulatum, Citrullus colocynthis, Gymnosporia royleana, Acacia jacquemontii, Acacia modesta, Phragmities australis and Nerium oleander etc having the highest scores are distributed over the Piedmont zone along maximum soil seed bank density and presented on the far left side of the ordination (Figure 4).

The stands located in the middle of the ordination (Figure 5) were laid on the Sandy alluvial plains. However a few stands were not followed this sequence suggesting some species specific factors. Although the distribution of

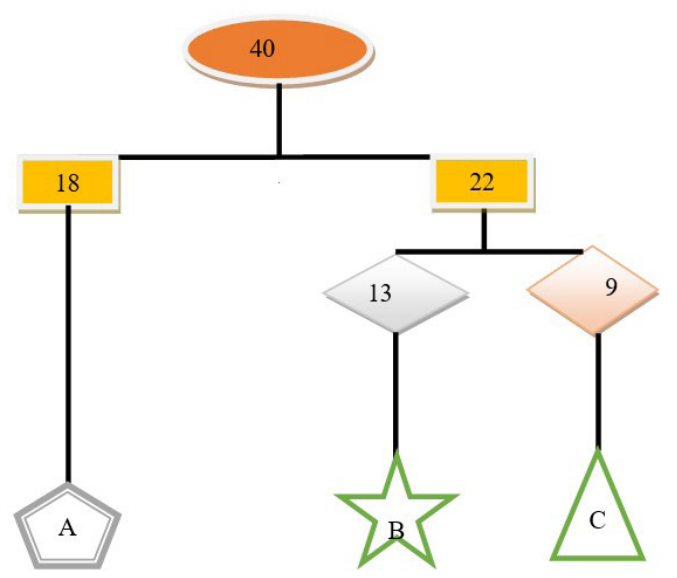

Figure 4. The hierarchical diagram of 40 sampling stands of soil seed bank segregated by normal cluster analysis.

stands along DCA axis-II is difficult to interpret, it seems the soil salt concentration (EC) played a significant role in this distribution. The soil chemical properties can be ranked in term of $R$-value and its significance, $R=$ soil EC $>$ soil organic matter $>$ Available Potassium > Available Phosphate $>\mathrm{pH}$ (Table 3 ). The results (Table 3 ) suggesting the importance of soil EC and soil organic matter content. The soil seed bank of riparian zone is slightly alkaline with high content of soil nutrients and control the higher species richness and diversity of emergence plants than the seed bank of piedmont zone located at high altitudinal inclination exhibited the lower values of richness and diversity of emergence (Table 3 ) and confirming the decreasing trends of seed bank $\left(R=-0.792^{* * *}\right.$, Table 3$)$ to harbor the emergent species are site specific or either emergent plant species. 


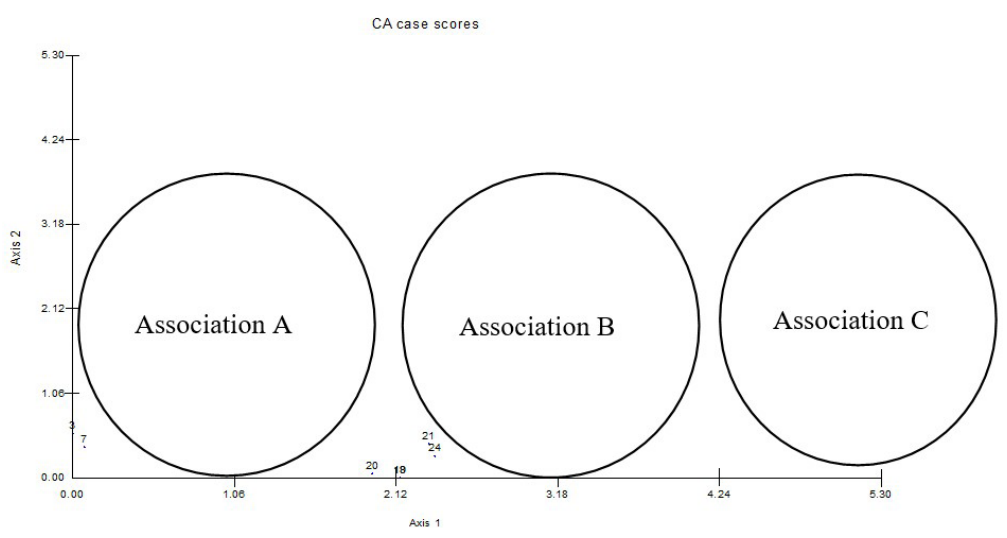

Figure 5. Decorana (axis-I \& axis-II) plot of the 40 stands. The associations segregated by the normal cluster analysis.

Table 3. Spearman correlation coefficients between detrended correspondence analysis (DCA) I and II axis scores and soil variables.

\begin{tabular}{|c|c|c|}
\hline Geo-climatic factors & Axis-I & Axis-II \\
\hline Elevation (m a.s.l) & $0.696^{* * *}$ & $0.056^{\mathrm{NS}}$ \\
\hline $\begin{array}{l}\text { Soil electrical conductivity } \\
\mathrm{EC}(\mu \mathrm{S})\end{array}$ & $-0.880^{* * *}$ & $0.026^{\mathrm{NS}}$ \\
\hline Soil reactions $(\mathrm{pH})$ & $-0.684^{* * *}$ & $0.118^{\mathrm{NS}}$ \\
\hline Organic matter $\%$ & $-0.827^{* * *}$ & 0.306 Ns \\
\hline Available Bicarbonates (ppm) & $-0.648^{* * *}$ & $0.494^{\mathrm{NS}}$ \\
\hline Available Calcium (ppm) & $-0.378^{* *}$ & $0.227^{\mathrm{NS}}$ \\
\hline Available Magnesium (ppm) & $-0.074^{\mathrm{NS}}$ & $0.041^{\mathrm{NS}}$ \\
\hline Available Sodium (ppm) & $-0.316^{* *}$ & $-0.051^{\mathrm{NS}}$ \\
\hline Available Potassium (ppm) & $-0.777^{* * *}$ & $-0.143^{\text {NS }}$ \\
\hline Available Phosphate (ppm) & $-0.714^{* * *}$ & $-0.143^{\text {NS }}$ \\
\hline Available Chloride (ppm) & $-0.112 \mathrm{NS}$ & $0.086^{\mathrm{NS}}$ \\
\hline $\begin{array}{l}\text { Seed Bank Supporting } \\
\text { No. of Species (SR) }\end{array}$ & $-0.792^{* * *}$ & $0.224^{\mathrm{NS}}$ \\
\hline Shannon Wiener Diversity ( $\left.\mathrm{H}^{\prime}\right)$ & $-0.726^{* * *}$ & $-0.319^{\mathrm{NS}}$ \\
\hline Simpson Diversity (D’) & $-0.763^{* * *}$ & $-0.019^{\mathrm{NS}}$ \\
\hline Brillion Diversity (B’) & $-0.713^{* * *}$ & $0.326^{\mathrm{NS}}$ \\
\hline
\end{tabular}

${ }^{*} P<0.05 .{ }^{* *} P<0.01 .{ }^{* * *} P<0.001$.

\subsection{Distribution pattern of soil seed bank}

The diversity and richness of soil seed bank richness decreased with the increases in elevation and there is a significant variation in pattern of distribution of seed bank for all the plant species (Table 1). The results showed that the riparian alluvial zone (association A) commonly have maximum soil seed bank of species richness and diversity than that of the association C (Piedmont) at high elevation (Table 1). This spatial pattern of distribution of soil seed bank richness might be partly attributed, to that the most severe drought, high temperature and water stress resulted from evaporation of ground destroyed the reproductive parts of most of plant species in piedmont zone, consequently the number of spikelets decreased dramatically, due to which number of emergent decreased. Dry and xerophytic environment of Piedmont zone increases the abortive seed number that caused reduction in viable seed bank (Zordoky, 2016). This distribution might be a result of accumulation of wind-blown seeds in sparsely disseminated micro-depressions in the soil surface, with seeds comparatively rare elsewhere (Broughton et al., 2021; Liu et al., 2020). Moreover, the low soil seed bank in Piedmont areas reflect the fact that in dry arid habitat various environmental stresses like, periodic aridity, high temperature, and physical and soil erosion caused lowering the density of seed bank (Clark et al., 2016). Seeds richness and diversity can be encountered not only by the rate of seed input, but also due to loss of seeds due to predation, senescence and germination (Madawala et al., 2016). Predation, senescence, germination and dormancy factors may have contributed to fluctuations of the soil seed banks. In the piedmont zone at high elevation (Association $\mathrm{C}$ ), the absence of tree and shrub species in the seed bank may be due to vulnerability of seeds to high predation and pathogen attacks during the rainy season, which is similar to the finding of (Hossain and Begum, 2015; Madawala et al., 2016). This phenomenon can also be elucidated by some inherent characteristics exhibited by non-woody species to produce higher number of seeds (Madawala et al., 2016). Current research work reveals that spatial patterns of soil seed bank (Table 3 ) is generally represented the distribution pattern of its associated standing vegetation. However, this reveals the adaptive and several strategies of perennial herb species in hazardous environment. In such environment plant species ensure their survival by sustaining persistent seed bank. The persistent seed bank ensure the perennial species to restore, when the condition are favorable for their establishment. The results described that the riparian alluvial zone (association $\mathrm{A}$ ) has a rich and diverse soil seed bank which is composed predominantly of seeds belonging to the monocot and dicot forbs plant groups. Seed bank is comparable to the most abundant species germinating from the soil seed bank in this study included the annual dicots herbaceous species such as Chenopodium 
album, Euphorbia prostrata, Eragrostis minor, Launaea procumbens, Nelumbo nucifera and Solanum xanthocarpum, Heliotropium eichwaldi, Scirpus maritimus, Dichanthium annulatum, Citrullus colocynthis, Gymno sporiaroyleana, Acacia jacquemontii, Acacia modesta, Phragmities australis and Nerium oleander species germinating from the soil seed bank in this investigation. This agrees with the findings of (Andreasen et al., 2018; Janicka, 2017). Ordination diagram (Figure 3) also confirmed the associations which were obtained by normal cluster analyis. The species belonging to association $C$ were grouped and existed at far right side of the ordination diagram and the species belonging to association A were grouped and existed at far left side of the ordination diagram with low score. These suggested that the habitats as well as edaphic factors like organic matter, exchangeable cations and anions, $\mathrm{pH}$, soil electrical conductivity played an essential role in distribution of soil seed bank, its richness and diversity. These findings were similar to studies of many ecologists made a research work comparable ecological level terrain areas (Faul, 2018).

\section{Conclusion}

In our current research work, the richness pattern of seedbank of Piedmont and Riparian environments at various altitudinal inclines have been described in District D.G.Khan. Topographically different landscapes are basic reason in providing the habitat for floral diversity. It was also proved inour findings that species richness is much more reduced at high altitude as compared to that at low altitude. There is a significant relationship between altitude and DCA-axis I which suggested that axis-I have prominent influenced on topography and the redistribution of rain water, which not only effect on the diversity of plant species but also on overall pattern of species richness. Species richness of this area showed significant negative correlation with cations, anions, while significant positive correlation with altitude inclines, suggested the effect of different parameters of environment on species richnee and diversity with overall pattern of vegetation in this area. Soil available soluble cations have shown significant negative correlation with DCA-axis I, indicated that the soil samples collected from high elevation have less concentrations of bivalent cations and anions, these sites have tendency to release less $\mathrm{H}^{+}$that is responsible for decrease of $\mathrm{pH}$ of sites at high altitude. Electrical conductivituy (E.C) of soil samples showed negative correlation with DCA-axis I significantly. Thus chemical composition of soil determined the pattern of distribution of species with respect to DCAaxis I. Moreover, the abundance of species with germinable seeds are exhibited by the results provided by emergence from green house. Infact these were the reflections of below ground vegetation inform of seeds of various species buried in the soil. The significant correlation of seed bank supporting emergence richness and diversity suggesting that species distribution along geological inclination is not only controlled by geo-climatic factors but also by the soil seed bank had intervening effect in composition of plant community.

\section{Acknowledgements}

All the co-authors are hereby thankfull for contributing in the paper writing, preparing, data analysis and submission.

\section{References}

ANDREASEN, C., JENSEN, H.A. and JENSEN, S.M., 2018. Decreasing diversity in the soil seed bank after 50 years in Danish arable fields. Agriculture, Ecosystems \& Environment, vol. 259, pp. 61-71.

BROUGHTON, R.K., BULLOCK, J.M., GEORGE, C., HILL, R.A., HINSLEY, S.A., MAZIARZ, M., MELIN, M., MOUNTFORD, J.O., SPARKS, T.H. and PYWELL, R.F., 2021. Long-term woodland restoration on lowland farmland through passive rewilding. PLoS One, vol. 16, no. 6, pp. e0252466. http://dx.doi.org/10.1371/journal. pone.0252466. PMid:34133452.

CALÇADA, E.A., LENOIR, J., PLUE, J., BROECKX, L.S., CLOSSET-KOPP, D., HERMY, M. and DECOCQ G., 2015. Spatial patterns of waterdeposited seeds control plant species richness and composition in riparian forest landscapes. Landscape Ecology, vol. 30, no. 10, pp. 2133-2146. http://dx.doi.org/10.1007/s10980-015-0236-y.

CAMPBELL, J.M. and SOFO, A., 2017. An integral transform related to series involving alternating harmonic numbers. Integral Transforms and Special Functions, vol. 28, no. 7, pp. 547-559. http://dx.doi.org/10.1080/10652469.2017.1318874.

CLARK, J.S., IVERSON, L., WOODALL, C.W., ALLEN, C.D., BELL, D.M., BRAGG, D.C., D'AMATO, A.W., DAVIS, F.W., HERSH, M.H., IBANEZ, I., JACKSON, S.T., MATTHEWS, S., PEDERSON, N., PETERS, M., SCHWARTZ, M.W., WARING, K.M. and ZIMMERMANN, N.E., 2016. The impacts of increasing drought on forest dynamics, structure, and biodiversity in the United States. Global Change Biology, vol. 22, no. 7, pp. 2329-2352. http://dx.doi.org/10.1111/ gcb.13160. PMid:26898361.

EL-KEBLAWY, A.A. and BHATT, A., 2015. Aerial seed bank affects germination in two small-seeded halophytes in Arab Gulf desert. Journal of Arid Environments, vol. 117, pp. 10-17.

FAUL, C., 2018. Correlations between vegetation, soil and geology in the semi-arid Bushmanland region of South Africa. Potchefstroom: North-West University, 245 p. Master of Science in Environmental Sciences.

GARCIA, A., ORENGO, H.A., CONESA, F.C., GREEN, A.S. and PETRIE, C.A., 2019. Remote sensing and historical morphodynamics of alluvial plains: the 1909 Indus flood and the city of Dera Ghazi Khan (province of Punjab, Pakistan). Geosciences, vol. 9, no. 1, pp. 21. http://dx.doi.org/10.3390/geosciences9010021.

HOSSAIN, M. and BEGUM, M., 2015. Soil weed seed bank: importance and management for sustainable crop production: a review. Journal of the Bangladesh Agricultural University, vol. 13, no. 2, pp. 221-228. http://dx.doi.org/10.3329/jbau.v13i2.28783.

ISSELIN-NONDEDEU, F. and SPIEGELBERGER, T., 2014. Alpine grasslands: changes of plant species composition and functional types after restoration and simulation of climate changes. In P. MARIOTTE and P. KARDOL, eds. Grassland biodiversity and conservation in a changing world. New York: Nova Publishers, pp. 219-250.

JANICKA, M., 2017. The evaluation of soil seed bank in two Arrhenatherion meadow habitats in central Poland. Acta Scientiarum Polonorum. Agricultura, vol. 15, no. 4, pp. 25-38.

KEIGHTLEY, A.N., 2020. Micro-propagated Sphagnum introduction to a degraded lowland bog: photosynthesis, growth and gaseous carbon fluxes. Manchester: Manchester Metropolitan University, 227 p. Thesis. 
KOCH, M.A., SCHERIAU, C., SCHUPFNER, M. and BERNHARDT, K.G., 2011. Long-term monitoring of the restoration and development of limestone grasslands in north western Germany: vegetation screening and soil seed bank analysis. Flora - Morphology, Distribution. Functional Ecology of Plants, vol. 206, no. 1, pp. 52-65. http://dx.doi.org/10.1016/j.flora.2010.01.010.

LAI, H.R., CHONG, K.Y., YEE, A.T.K., TAN, H.T.W. and VAN BREUGEL, M., 2020. Functional traits that moderate tropical tree recruitment during post-windstorm secondary succession. Journal of Ecology, vol. 108, no. 4, pp. 1322-1333. http://dx.doi. org/10.1111/1365-2745.13347.

LIU, W., SUN, S. and WEI, Z., 2020. Linking phytogenic hillocks with plant ecological strategies in a desert steppe: adaptation of Stipa breviflora to heavy grazing. Ecological Indicators, vol. 117, pp. 106564. http://dx.doi.org/10.1016/j.ecolind.2020.106564.

LONG, R.L., GORECKI, M.J., RENTON, M., SCOTT, J.K., COLVILLE, L., GOGGIN, D.E., COMMANDER, L.E., WESTCOTT, D.A., CHERRY, H. and FINCH-SAVAGE, W.E., 2015. The ecophysiology of seed persistence: a mechanistic view of the journey to germination or demise. Biological Reviews of the Cambridge Philosophical Society, vol. 90, no. 1, pp. 31-59. http://dx.doi.org/10.1111/ brv.12095. PMid:24618017.

LURIE, D. and WAGENSBERG, J., 1985. An extremal principle for biomass diversity in ecology. In I. LAMPRECHT and A.I. ZOTIN, eds. Thermodynamics and regulation of biological processes. Berlin/Boston: De Gruyte, pp. 257-274.

MADAWALA, H., EKANAYAKE, S., and PERERA, G., 2016. Diversity, composition and richness of soil seed banks in different forest communities at Dotalugala Man and Biosphere Reserve, Sri Lanka. Ceylon Journal of Science, vol. 45, no. 1, pp. 43-55.

MAHÉ, I., CORDEAU, S., BOHAN, D.A., DERROUCH, D., DESSAINT, F., MILLOT, D. and CHAUVEL, B., 2021. Soil seedbank: old methods for new challenges in agroecology? Annals of Applied Biology, vol. 178, no. 1, pp. 23-38. http://dx.doi.org/10.1111/aab.12619.

MENSAH, A.K., 2015. Role of revegetation in restoring fertility of degraded mined soils in Ghana: a review. International Journal of Biodeversity and Conservation, vol. 7, no. 2, pp. 57-80. http:// dx.doi.org/10.5897/IJBC2014.0775.

MUNIR, B.A. and IQBAL, J., 2016. Flash flood water management practices in Dera Ghazi Khan City (Pakistan): a remote sensing and GIS prospective. Natural Hazards, vol. 81, no. 2, pp. 13031321. http://dx.doi.org/10.1007/s11069-015-2136-5.

SANOU, L., ZIDA, D., SAVADOGO, P. and THIOMBIANO, A., 2018. Comparison of aboveground vegetation and soil seed bank composition at sites of different grazing intensity around a savanna-woodland watering point in West Africa. Journal of Plant Research, vol. 131, no. 5, pp. 773-788. http://dx.doi. org/10.1007/s10265-018-1048-3. PMid:29948487.

SANTOS, D.M., SANTOS, J.M.F.F., SILVA, K.A., ARAÚJO, V.K.R. and ARAÚJO, E.L., 2016. Composition, species richness, and density of the germinable seed bank over 4 years in young and mature forests in Brazilian semiarid regions. Journal of Arid Environments, vol. 129, pp. 93-101.

SCHWARTZ-LAZARO, L.M. and COPES, J.T., 2019. A review of the soil seedbank from a weed scientists perspective. Agronomy, vol. 9, no. 7, pp. 369. http://dx.doi.org/10.3390/agronomy9070369.

SHANG, Z., YANG, S., WANG, Y., SHI, J., DING, L. and LONG, R., 2016. Soil seed bank and its relation with above-ground vegetation along the degraded gradients of alpine meadow. Ecological Engineering, vol. 90, pp. 268-277.

SHIELS, A.B. and DRAKE, D.R., 2015. Barriers to seed and seedling survival of once-common Hawaiian palms: the role of invasive rats and ungulates. AoB Plants, vol. 7, pp. plv057. http://dx.doi. org/10.1093/aobpla/plv057. PMid:26019231.

THEOCHAROPOULOS, S.P., WAGNER, G., SPRENGART, J., MOHR, M.E., DESAULES, A., MUNTAU, H., CHRISTOU, M. and QUEVAUVILLER, P., 2001. European soil sampling guidelines for soil pollution studies. The Science of the Total Environment, vol. 264, no. 1-2, pp. 51-62. http://dx.doi.org/10.1016/S0048-9697(00)00611-2.PMid:11213188.

VEEN, G., FRY, E.L., TEN HOOVEN, F.C., KARDOL, P., MORRIËN, E. and DE LONG, J.R., 2019. The role of plant litter in driving plant-soil feedbacks. Frontiers in Environmental Science, vol. 7, pp. 168. http://dx.doi.org/10.3389/fenvs.2019.00168.

WASEEM, M., KHURSHEED, T., ABBAS, A., AHMAD, I., and JAVED, Z., 2021. Impact of meteorological drought on agriculture production at different scales in Punjab, Pakistan. Journal of Water and Climate Change, vol. 00, pp. 1-12.

ZORDOKY, M., 2016. Essential oil and extract constituents of medicinal plants from Egypt. Vienna: University of Vienna, 72 p. Magister der Pharmazie. 